Elsevier

IIRR 00646

\title{
Hormonal regulation of adenylate cyclase in the stria vascularis of the mouse
}

\author{
Jochen Schacht \\ Kresge Hearing Research Institute, University of Michigan, Ann Arbor, MI 48109, U.S.A.
}

(Received 9 May 1985; accepted 23 July 1985)

\begin{abstract}
The adenylate cyclase complex is a ubiquitous "second-messenger" system mediating the actions of hormones and neurotransmitters. Its presence but not its physiological control and function had previously been established in the cochlea.

In this study, the hormonal stimulation of adenylate cyclase activity of the stria vascularis of the CBA mouse was characterized. In the presence of the regulatory nucleotide, GTP, the enzyme was stimulated by isoproterenol and epinephrine with a half-maximal effect at about $10 \mu \mathrm{M}$ and the stimulation was blocked by propranolol. This profile is consistent with the presence of adrenergic $\beta_{2}$-receptors on the strial enzyme complex. Hormones and neuromodulators preferring other receptor subtypes were ineffective; the non-specific stimulator, forskolin, activated the enzyme. The finding that potential hormonal effectors of water and ion transport including vasopressin were inactive may be significant with regard to the physiological role of strial adenylate cyclase.
\end{abstract}

adenylate cyclase, stria vascularis, adrenergic receptors. epinephrine, forskolin

\section{Introduction}

The presence of adenylate cyclase in the inner ear is firmly established. The membrane-bound enzyme is distributed in all labyrinthine structures and shows highest activity in stria vascularis (Ahlström et al., 1975; Bagger-Sjöbäck et al., 1980; Zajic et al., 1983). Adenylate cyclase is part of a second-messenger system which may mediate the effects of hormones and neurotransmitters on a wide variety of cellular reactions.

The important issue of the hormonal regulation of adenylate cyclase in the inner ear was first addressed by Zenner and Zenner (1979) who reported that an enzyme preparation from the whole cochlea was responsive to isoproterenol and vasopressin. Although the site of action of these agonists remained open, this finding promoted the discussion of the involvement of the strial enzyme in cochlear ion and fluid balance, a question as yet unresolved (for a review, see Schacht, 1982).

We have previously determined adenylate cyclase in labyrinthine tissues (Bagger-Sjöbäck et al., 1980) and localized its activity in stria vascularis to the contraluminal infoldings of the margi- nal cells (Zajic et al., 1983). The present study was designed to define the hormonal regulation of the strial adenylate cyclase.

\section{Methods}

Stria vascularis was obtained from CBA mice (20-25 g: Jackson Laboratories, Bar Harbor, ME). Inner ears were dissected in cold $300 \mathrm{mM}$ sucrose $/ 5 \mathrm{mM}$ Tris-acetate, $\mathrm{pH}$ 7.4. Stria were collected in a glass homogenizer in $25 \mathrm{mM}$ Trisacetate, $\mathrm{pH} 7.4$, with $1 \mathrm{mM}$ dithioerythritol (DTE). Homogenization (tissue from two ears per each $100 \mu 1$ ) was carried out with a teflon pestle: 5 strokes by hand were followed by $15 \mathrm{~s}$ of mechanical rotation of the pestle at approximately $600 \mathrm{rpm}$. The homogenate was centrifuged for $5 \mathrm{~min}$ at $12000 \times g$ and the supernatant discarded. The pellet was resuspended in cold homogenization buffer to the initial volume.

Incubations for the formation of cyclic AMP were performed at $36^{\circ} \mathrm{C}$ in $25 \mathrm{mM}$ Tris-acetate. $5 \mathrm{mM} \mathrm{MgCl}_{2}, 0.5 \mathrm{mM}$ ATP, $0.02 \mathrm{mM}$ GTP. $0.2 \mathrm{mM}$ isobutylmethylxanthine (as phosphodiesterase inhibitor), $1 \mathrm{mM} \mathrm{DTE}, 0.1 \%$ bovine 
serum albumin and $5 \mathrm{mM}$ creatine phosphate $/ 5$ units creatine phosphokinase (as an ATP-regenerating system); final $\mathrm{pH}, 7.4$. Incubations were started by the addition of the enzyme preparation (approximately $3 \mu \mathrm{g}$ of protein per assay tube) to yield a final volume of $100 \mu \mathrm{l}$. The incubations were terminated by the addition of $25 \mu \mathrm{l}$ of $20 \%$ trichloroacetic acid and centrifuged for $10 \mathrm{~min}$ at $1000 \times \mathrm{g}$. Cyclic AMP was isolated from the supernatant by passage over a small column of Dowex $50\left(\mathrm{H}^{+}\right)$(Steiner, 1974) and analyzed by radioimmunoassay (Becton-Dickinson, Orangeburg, NY).

Chemicals were reagent grade. Drugs were purchased from Sigma (St. Louis, MO) except forskolin which was from Cal Biochem (La Jolla, CA).

\section{Results}

After homogenization and centrifugation the enzymatic activity was found in the pelleted material. This was consistent with previous descriptions of the cochlear enzyme as membrane-associated (Zajic et al., 1983; Zenner and Zenner, 1979).

Formation of cyclic AMP was essentially linear up to $60 \mathrm{~min}$ of incubation (Fig. 1). The addition of $0.1 \mathrm{mM}(-)$-isoproterenol increased cyclic AMP formation by about $100 \%$ at all times. A $30 \mathrm{~min}$ time was chosen for subsequent experiments. The presence of guanyl nucleotide elevated enzymatic activity and promoted the expression of stimulation with a maximal effect around $10 \mu \mathrm{M}$ GTP (Fig. 2). The non-hydrolysable GTP analog, guanylylimidodiphosphate (GMP-PNP), could substitute for GTP and was equipotent to $10 \mu \mathrm{M}$ GTP at about $0.3 \mu \mathrm{M}$. Higher concentrations of GMP-PNP increased cyclic AMP formation up to 25 -fold (at $10 \mu \mathrm{M}$ ) but the stimulation by isoproterenol was attenuated $(21 \pm 5 \%$ stimulation at 10 to $100 \mu \mathrm{M}$ vs. $110 \pm 37 \%$ at $0.01-0.3 \mu \mathrm{M}$ GMPPNP).

The hormone epinephrine also stimulated cAMP formation with a half-maximal effect at $10 \mu \mathrm{M}$ (Fig. 3). The maximal stimulation was somewhat less than that achieved with isoproterenol (Table I). The $\beta$-antagonist propranolol blocked the stimulation both by isoproterenol (Table I) and by epinephrine (Fig. 3).
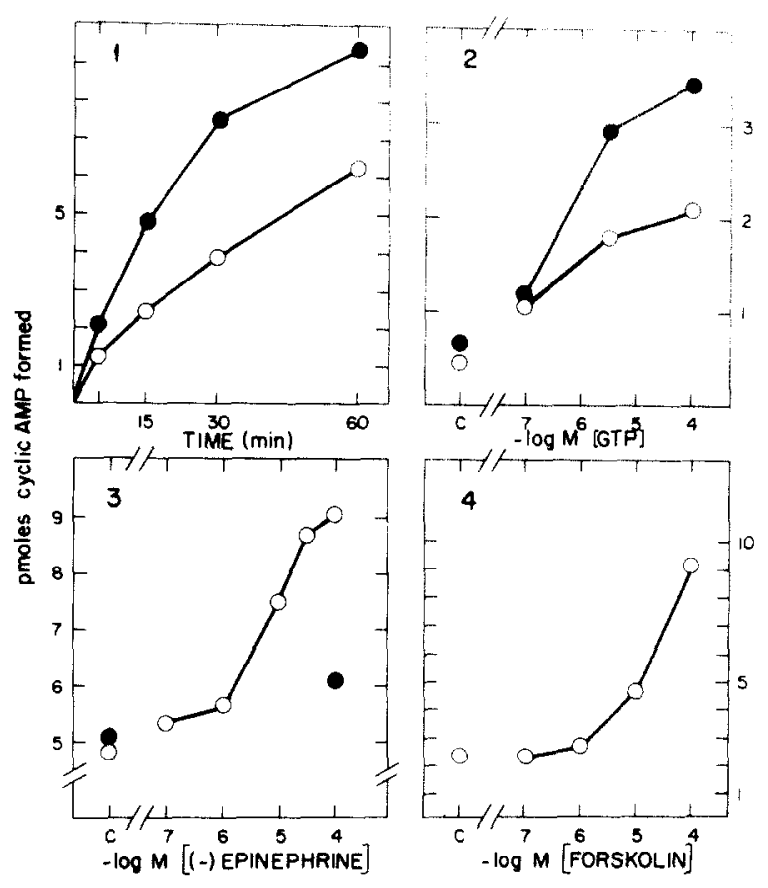

Figs. 1-4. Effect of time and drug concentrations on the formation of cyclic AMP by strial adenylate cyclasc. All incubations were performed with particulate fractions of stria vascularis (approx. $3 \mu \mathrm{g}$ protein/incubation) for $30 \mathrm{~min}$ as described in Methods with the variations noted below. All figures are from single experiments with each determination in duplicate.

Fig. 1. Time-course. $O$, controls; $\bullet+0.1 \mathrm{mM}$ isoproterenol.

Fig. 2. Effect of guanosine 5-triphosphate (GTP). O, controls; - $+0.1 \mathrm{mM}$ isoproterenol. ' $\mathrm{C}$ ' on the abscissa, control without GTP.

Fig. 3. Effect of (-)-epinephrine. $O$, variable concentrations of epinephrine as indicated; ' $\mathrm{C}$ ' on the abscissa, control without epinephrine. addition of $50 \mu \mathrm{M}$ propranolol.

Fig. 4. Effect of forskolin. A forskolin stock solution was prepared in ethanol and controls received equivalent amount of alcohol (less than $10 \%$ of total assay volume). ' $C$ ' on the abscissa, control without forskolin.

Norepinephrine, a $\beta_{1}$-agonist, as well as a number of selected hormones and neurotransmitters did not affect strial adenylate cyclase (Table II). Particular attention was paid to vasopressin (lysine-vasopressin) which was tested over a 10000 -fold concentration range and assays were performed in the absence of guanyl nucleotide, in the presence of $0.1 \mathrm{mM}$ dopamine and with homogenates prepared under inclusion of $10 \mu \mathrm{M}$ phenyl 
TABLE I

\section{ADRENERGIC CONTROL OF STRIAL ADENYLATE CYCLASE}

Particulate fractions from stria vascularis were incubated for $30 \mathrm{~min}$ as described in Methods. Values are means \pm S.E. for the number of experiments $(n)$ indicated.

\begin{tabular}{lcr}
\hline $\begin{array}{l}\text { Drugs added } \\
(0.1 \mathrm{mM})\end{array}$ & $\begin{array}{c}\text { cAMP formed } \\
\text { (as \% of control) }\end{array}$ & $n$ \\
\hline None & 100 & 8 \\
$\begin{array}{l}\text { (-)-Isoproterenol } \\
\text { DL-Propranolul }\end{array}$ & $215 \pm 12^{*}$ & 14 \\
Isoproterenol plus & $95 \pm 6$ & 6 \\
propranolol & $86 \pm 8$ & \\
(-)-Epinephrine & $189 \pm 11^{*}$ & 6 \\
L-Norepinephrine & $112 \pm 7$ & 15 \\
\hline
\end{tabular}

* Differs from control, $P<0.001$.

methylsulfonyl fluoride, a protease inhibitor (Zenner and Zenner, 1979). No consistent stimulation of adenylate cyclase was observed under any of these conditions and no dose-response curve could be obtained.

Forskolin, a diterpene activator of adenylate cyclase (Seamon et al., 1981), was effective on the strial enzyme (Fig. 4). At $100 \mu \mathrm{M}$ a 4- to 5-fold increase of activity was observed consistent with the range of stimulation of 2- to 15 -fold that has been reported for the enzyme from a variety of tissues (Seamon et al., 1981). The presence of

TABLE II

AGONISTS WITHOUT EFFECT ON STRIAL ADENYLATE CYCLASE

The following agents were tested for stimulation of strial adenylate cyclase as described in Methods. $n$ represents the number of incubations in which a drug was tested. Each set of experiments included isoproterenol as a positive control.

\begin{tabular}{llr}
\hline Agonist & $\begin{array}{l}\text { Concentrations tested } \\
(\mu \mathrm{M})\end{array}$ & $n$ \\
\hline L-Norepinephrine & 100 & 4 \\
Dopamine & 100 & 14 \\
Histamine & $1: 100$ & 8 \\
5-Hydroxytryptamine & $1 ; 100$ & 8 \\
Vasoactive Intestinal Peptide & $0.01-10$ & 8 \\
Vasopressin & $0.01-100$ & 20 \\
Prostaglandin E & $0.01-100$ & 14 \\
Parathyroid hormone & $10^{-6}-1$ unit & 14 \\
\hline
\end{tabular}

guanine nucleotide was not necessary for the expression of the forskolin effect, in agreement with observations on adenylate cyclase from rat cerebral cortex (Seamon et al., 1981).

\section{Discussion}

The adenylate cyclase complex serves as an important transmembrane signaling mechanism. Its activity is controlled by hormones and neurotransmitters that interact with specific receptors on the external surface of the plasma membrane. Binding to the receptor stimulates adenylate cyclase to produce cyclic AMP intracellularly. Cyclic AMP, in turn initiates a reaction cascade that culminates in the final biological response. In addition to the receptor and the catalytic unit, the complex contains at least one more component, a GTP-binding protein regulating the interaction between the hormone receptor and the catalytic subunit (Lefkowitz et al., 1982). Mediated by this system are some of the effects of transmitters such as norepinephrine, dopamine, histamine and 5-hydroxytryptamine, of hormones such as epinephrine, vasopressin and glucagon, or of local modulators such as prostaglandins. Depending on the receptor and tissue involved diverse cellular processes are controlled such as glycogenolysis and lipolysis, membrane permeabilities and secretion. or postsynaptic electrical activity (Schramm and Selinger, 1984).

The present study demonstrates that strial adenylate cyclase is under adrenergic control. More specifically, the profile of activation, isoproterenol $>$ epinephrine $\gg$ norepinephrine, and the block by propranolol are consistent with a regulation via $\beta_{2}$-adrenergic receptors. In contrast to the neurotransmitter-linked junctional $\beta_{1}$-receptors these are hormonal extra-junctional receptors, typically found in tissues without sympathetic innervation (Ariens and Simmonis, 1983). Hormones acting on these receptors generally modulate cellular metabolic activity.

Tests of selected agonists did not demonstrate another hormone-sensitive adenylate cyclase in the strial preparation. Dopamine, histamine, 5-hydroxytryptamine, mainly associated with adenylate cyclase in neuronal pathways in regions of the CNS, were ineffective further providing a control 
for the specificity of epinephrine. Notably absent was a stimulation by vasopressin which has a reported effect on adenylate cyclase from the whole cochlea. While a number of reasons could explain this difference (e.g., animal species; differences in enzyme preparation and assay), the simplest argument is that a vasopressin-stimulated adenylate cyclase is associated with a structure in the cochlea other than stria vascularis. This possibility is strengthened by the fact that our enzyme preparation is sensitive to isoproterenol to about the same extent as reported by Zenner and Zenner (1979). Vasoactive intestinal peptide (VIP), prostaglandin $\mathrm{E}_{1}\left(\mathrm{PG} \mathrm{E}_{1}\right)$ and parathormone $(\mathrm{PTH})$ are potential effectors of an adenylate cyclase linked to ion or water transport: for example, VIP and the PGEs increase intestinal fluid and electrolyte secretion (Kimberg, 1974). Although not reported in detail, both compounds have been suggested to be present in the cochlea (Lim et al., 1983; Matthias, 1983). PTH has a physiological action on the kidney affecting the excretion of phosphate, $\mathrm{K}^{+}$. $\mathrm{H}^{+}$and $\mathrm{NH}_{4}^{+}$and the tubular reabsorption of $\mathrm{Ca}^{2+}$ and $\mathrm{Mg}^{2+}$. None of these agonists was able to activate adenylate cyclase in stria vascularis. These observations considerably weaken the argument that the strial enzyme is involved in the control of endolymphatic ion and fluid balance (Schacht, 1982).

Forskolin, a natural diterpene, is a known stimulator of adenylate cyclase in a variety of tissues (Seamon et al., 1981). Its action differs from that of the hormones in that it activates the catalytic subunit of the enzyme directly. It may thus be a useful tool for studying the presence of adenylate cyclase in tissues in vitro as well as histochemically. It may also prove useful in elevating intracellular cAMP concentrations to study the physiological actions of the adenylate cyclase system regardless of hormonal stimulation. While other non-hormonal activators such as $\mathrm{NaF}$ and guanylylimidodiphosphate stimulate broken cell preparations their use in vivo is limited by their restricted penetration of the cell membrane. In fact, forskolin seems to be an even more powerful stimulator of adenylate cyclase in intact cells than in broken cell preparations (Seamon et al., 1981).

Current pharmacological evidence as to the physiological role of strial adenylate cyclase is insufficient. Electrophysiological data after cochlear perfusion of $\alpha$ - or $\beta$-adrenergic agents still remain inconclusive yet generally point to the lack of a specific effect (Ahlström et al., 1975: Comis and Leng, 1979; Klinke and Evans, 1977; Marcus et al., 1982). Endolymphatic application of cholera toxin, a stimulant of adenylate cyclase, was reported to increase endolymph volume (Feldman and Brusilow, 1976) but cyclic AMP levels in cochlear tissues were not significantly altered (Thalmann et al., 1982). The current study is the first one to characterize the hormonal regulation of adenylate cyclase in an individual tissue of the inner ear. If we obtain similar information about the regulatory mechanisms in other labyrinthine structures we may be able to examine the effects of adenylate cyclase on the cochlear physiology and electrophysiology with the use of tissue-specific hormones.

\section{Acknowledgements}

The author acknowledges the help of Mr. Timothy Mather in this study. This work was supported by NIH grant NS-05785 and a grant from the Biomedical Research Council, the University of Michigan.

\section{References}

Ahlström, P., Thalmann, I., Thalmann, R. and Ise, I. (1975): Cyclic AMP and adenylate cyclase in the inner ear. Laryngoscope $85,1241-1258$.

Ariens, E.J. and Simmonis, A.M. (1983): Physiological and pharmacological aspects of adrencrgic receptor classification. Biochem. Pharmacol. 32, 1539-1545.

Bagger-Sjöbäck, D., Filipek, C.S. and Schacht, J. (1980): Characteristics and drug responses of cochlear and vestibular adenylate cyclase. Arch. Otorhinolaryngol. 228, 217-222.

Comis, S.D. and Leng, G. (1979): Action of putative neurotransmitters in the guinea pig cochlea. Exp. Brain Res. 36 , 119-128.

Feldman, A.M. and Brusilow, S.W. (1976): Effects of cholera toxin on cochlear endolymph production: model for endolymphatic hydrops. Proc. Natl. Acad. Sci. U.S.A. 73, 1761-1764.

Kimberg, D.V. (1974): Cyclic nucleotides and their role in gastrointestinal secretion. Gastroenterology 67, 1023-1064.

Klinke, R, and Evans, E.F. (1977): Evidence that catecholamines are not the afferent transmitter in the cochlea. Exp. Brain Res. 28, 315-324.

Lefkowitz, R.J., Caron, M.G., Michel, T. and Stadel, J.M. (1982): Mechanisms of hormone receptor-effector cou- 
pling: the $\beta$-adrenergic receptor and adenylate cyclase. Fed. Proc. 41, 2664-2670.

Lim, D.J., Mogi, G., O'Dorisio, T.M. and Cataland, S. (1983): Vasoactive intestinal peptide in perilymph. In: Fourth Meeting, Assoc. for Otolaryngol., St. Petersburg, FL, 1981.

Marcus, D.C., Ge, X.X. and Thalmann, R. (1982): Comparison of the non-adrenergic action of phentolamine with that of vanadate on cochlear function. Hearing Res. 7, 233-246.

Matthias, R. (1983): Prostaglandin deficit and inner ear function. In: 20th Workshop on Inner Ear Biology, Geilo, Norway, 1983.

Schacht. J. (1982): Adenylate cyclase and cochlear fluid balance. Am. J. Otolaryngol. 3, 328-331.

Schramm, M. and Selinger, Z. (1984): Message transmission: receptor controlled adenylate cyclase system. Science 225 , 1350-1356.
Seamon, K.B., Padgett, W, and Daly, J.W. (1981): Forskolin: unique diterpene activator of adenylate cyclase in membranes and in intact cells. Proc. Natl. Acad. Sci. U.S.A. 78 , 3363-3367.

Steiner, A.L. (1974): Assay of cyclic nucleotides by radioim. munoassay methods. Methods Enzymol. 38, 96-105.

Thalmann, I., DeMott, J.E., Ge, X.X. and Thalmann, R. (1982): Effect of cholera toxin upon cyclic AMP levels in tissues lining cochlear duct. J. Acoust. Soc. Am. 71, S99.

Zajic, G., Anniko, M. and Schacht, J. (1983): Cellular localization of adenylate cyclase in the developing and mature inner ear of the mouse. Hearing Res. 10, 249-261.

Zenner, H.P. and Zenner, B. (1979): Vasopressin and isoproterenol activate adenylate cyclase in the guinea pig inner ear. Arch. Otorhinolaryngol. 222, 275-283. 